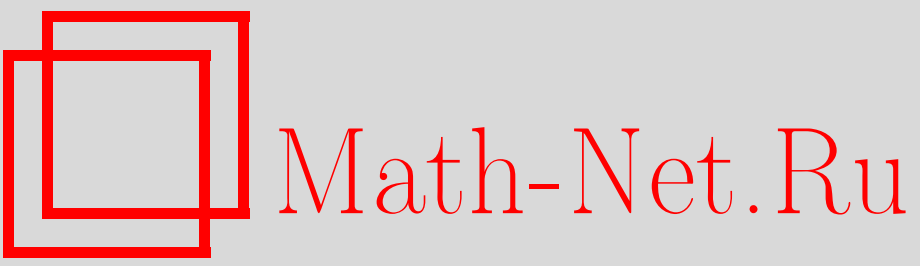

Н. А. Бобылев, Е. А. Горин, А. Ю. Ишлинский, С. П. Новиков, В. М. Тихомиров, Марк Александрович Красносельский (некролог), УМН, 1998, том 53, выпуск 1, 199-201

DOI: https://doi.org/10.4213/rm2

Использование Общероссийского математического портала Math-Net.Ru подразумевает, что вы прочитали и согласны с пользовательским соглашением

http: //www. mathnet.ru/rus/agreement

Параметры загрузки:

IP : 54.172 .240 .79

26 апреля 2023 г., 13:19:08 


\section{МАРК АЛЕКСАНДРОВИЧ КРАСНОСЕЛЬСКИЙ}

Утром 13 февраля 1997 года в своей московской квартире скоропостижно скончался Марк Александрович Красносельский, выдающийся ученьй и педагог, один из основоположников современного нелинейного функционального анализа.

М.А. Красносельский родился 27 апреля 1920 года в г. Староконстантинове на Украине. Его отец Александр Яковлевич был инженером-строителем, погиб во время войны. Мать Марка Александровича, Фанни Моисеевна, была школьной учительницей.

По окончании в 1938 году средней школы в Бердянске Марк Александрович поступил на физико-математический факультет Киевского университета. Университет он закончил в 1942 году уже в эвакуации, в Казахстане, после чего четыре года служил в армии.

После демобилизации в 1946 году Марк Александрович возвращается в Киев, ведет преподавательскую работу, работает в Институте математики АН Украины. В 1948 году он защитил кандидатскую диссертацию по теории расширений эрмитовых операторов, а в 1950-м - докторскую по топологическим методам нелинейного анализа.

В 1953 году семья Красносельских переехала в Воронеж, и там прошел длившийся свыше 15 лет один из самых ярких периодов научной, педагогической и организационной деятельности Марка Александровича.

Это были годы рождения замечательной воронежской школы функционального анализа, во

главе которой стояли М. А. Красносельский и С. Г. Крейн. Воронеж стал одним из самых значительных математических центров в СССР. Многие поколения отечественных математиков прошли знаменитые Воронежские зимние математические школы, одной из центральных фигур которых на протяжении ряда лет оставался М. А. Красносельский.

В 1968 году Марк Александрович переселился в Москву и возглавил лабораторию математических методов анализа сложных систем в Институте автоматики и телемеханики (ньне это Институт проблем управления). В его творческой деятельности все большее и большее место начинают занимать прикладные проблемы теории управления, гистерезис, затем - динамика систем с гистерезисом, импульсные рассинхронизированные системы и т. п.

В 1990 году М.А. Красносельский перешел в Институт проблем передачи информации АН СССР. Там он проработал до последних дней жизни, активно продолжая многочисленные фундаментальные и прикладные исследования. 
За день до кончины Марк Александрович увлеченно обсуждал план новой монографиии. Смерть (непосредственной причиной был разрьв аорты) застала его за рабочим столом.

Творческая деятельность М.А. Красносельского продолжалась более полувека. Своими учителями он называл многих математиков, но наибольшее влияние на его становление оказали М.Г. Крейн и Л.А. Люстерник. Марк Александрович неизменно подчеркивал также влияние на него личности и творчества А.Н. Колмогорова.

От М.Г. Крейна Марк Александрович воспринял важнейшие концепции линейного анализа, теорию нормированных пространств, теорию расширений линейных операторов, упорядоченных конусами, интерес к классическому анализу, теории дифференциальных уравнений, а также внимательное и вдумчивое отношение к работам предшественников (А.М. Ляпунова, А.А. Маркова, Дж. фон Неймана и др.). Вместе с М.Г. Крейном М.А. Красносельский сделал несколько очень значительных работ.

Знакомство М.А. Красносельского с Л.А. Люстерником, в основном, было заочным. Однако именно от Лазаря Ароновича Марк Александрович получил многое из того, что в заметной степени определило его математическое кредо, - в первую очередь, основные концепции нелинейного анализа: топологические и вариационные методы исследования бесконечномерных структур.

Основная область математических исследований М.А. Красносельского - нелинейный анализ.

Первая публикация М.А. Красносельского датируется 1946 годом. Его первые работы по нелинейному анализу появились в 1949 году, а в дальнейшем это направление стало доминирующим. Любопытно, что топологические соображения и раньше успешно срабатьвали у Марка Александровича. Скажем, в доказательстве его знаменитой теоремы о растворе подпространств ключевую роль сыграла теорема Борсука.

Для М.А. Красносельского (во всяком случае в воронежский период) была характерной такая стратегия. Начиная входить в новую для себя область математики, он изучал литературу, читал спецкурсы, вовлекал в работу учеников, а получив основополагающие результаты, публиковал краткие сообщения и принимался за книгу. М.А. Красносельский является автором более 350 публикаций, из которых 14 (не считая переводов и переизданий) - монографии, написанные, как правило, совместно с кем-нибудь из сотрудников. Список основных монографий приведен в конце данного текста. Первые 10 из них относятся к воронежскому периоду, и дают представление об исключительной плодотворности Марка Александровича и многогранности его таланта. Вместе с тем, ясно, что важнейшая компонента всех этих исследований тесно связана с разнообразными принципами существования решений нелинейных уравнений в бесконечномерных пространствах и приложениями к интегральньм уравнениям. Важную роль, как правило, играли соображения, связанные с компактностью, монотонностью и, разумеется, - с топологическими идеями. Топологические идеи всегда оставались центральными в исследованиях Марка Александровича, развитие и применение этих идей принесли ему наибольшую известность в математическом мире и за его пределами.

М.А. Красносельский развил и углубил теорию Люстерника-Шнирельмана и довел до высокого уровня теорию Пуанкаре-Брауэра степени отображений как аппарата бесконечномерного анализа. Применение принципов компактности требовало развития дифференциального исчисления в бесконечномерных пространствах, и в школе Красносельского были разработаны многие разделы, касающиеся свойств оператора Немыцкого и его суперпозиций с интегральными операторами, а это позволило создать глубокую новую теорию нелинейных интегральных уравнений. Следует отметить, что решенные проблемы интересовали в этот период широкий круг математиков.

Вслед за М.Г. Крейном М.А. Красносельский очень далеко продвинул теорию монотонных операторов. В этом направлении школа Красносельского стала лидирующей в мире.

В московский период М. А. Красносельский издал еще четыре книги. Две из них посвящены его традиционным темам - топологии и порядку, а две другие - новым вопросам, возникшим в связи с прикладньми проблемами, к которым у Марка Александровича сохранялся неослабевающий интерес. Он обладал редким талантом находить общий язьк не только со своими коллегами-математиками самых разнообразных специальностей, но и с инженерами, биологами, экономистами и т.д., что позволяло ему организовывать плодотворно работающие коллективы из людей, которые без вмешательства М. А. Красносельского вряд ли когда-нибудь 
нашли друг друга.

Марк Александрович был яркой и самобытной личностью, веселым и остроумным человеком, очень доброжелательным, терпимым и контактным. Многие из тех, кому доводилось общаться с Марком Александровичем, искренне считали (и, по-своему, были правы!), что наиболее доверительные отношения у него были именно с ними. Его интересовало многое - спорт и политика, рыбалка и хорошие книги, но главным в его жизни было общение с человеком, и каждый, кто с ним сталкивался, встречал искреннюю заинтересованность.

В большом ученом М.А. Красносельском поражали его увлеченность, азарт, целеустремленность и невероятная работоспособность, хотя жизненные обстоятельства далеко не всегда складывались благоприятно для научной работы.

В первые послевоенные годы семья Красносельских, как и большинство семей в нашей стране, жила весьма стесненно (комната в коммунальной квартире, где Марк Александрович и Сарра Израилевна жили с двумя детьми). В памяти детей осталось: когда бы они ни проснулись, перед ними была одна и та же картина - склонившийся над рукописью отец, сидящий за столом (разумеется, за единственньм столом, "рабочих"столов тогда не существовало).

В те годы Марку Александровичу приходилось совмещать работу в Математическом институте с преподаванием, причем педагогическая нагрузка была невероятной - до 48 аудиторных часов в неделю. Марк Александрович рассказьвал, что обдумьвал свою докторскую диссертацию во время объяснений и записьвал мысли, когда давал студентам самостоятельную работу.

Через всю жизнь пронес Марк Александрович наивную и светлую любовь к нашей науке. При каждой встрече с ним можно было услышать слова восторга по поводу очередной красивой идеи или конструкции (не обязательно своей) или неопровержимые доводы в пользу того, что "пора тебе это бросить и заняться вот такой задачей..."

Марк Александрович гордился своими учениками. Никто не берется подсчитать, скольких докторов наук он воспитал (не менее 30). Сейчас научных детей, внуков и правнуков М. А. Красносельского можно встретить в любой стране, в которой можно встретить хотя бы одного математика.

Его утрата горька и невосполнима, но его след останется в сердцах людей и в истории науки.

Н. А. Бобълев, Е. А. Горин, А. Ю. Иилинский, С. П. Новиков, В. М. Тихомиров

\section{МОНОГРАФИИ М.А. КРАСНОСЕЛЬСКОГО}

[1] Топологические методы в теории нелинейных интегральных уравнений. М.: ГТТИ, 1956

[2] Вьпуклые функции и пространства Орлича. М.: Физматгиз, 1958 (совм. с Я. Б. Рутицким)

[3] Положительные решения операторных уравнений. М.: Физматгиз, 1962

[4] Векторные поля на плоскости. М.: Физматгиз, 1963 (совм. с П.П. Забрейко)

[5] Функциональньй анализ. М.: Физматгиз, 1964 (совм. с П.П. Забрейко и др.)

[6] Оператор сдвига по траекториям дифференциальных уравнений. М.: Физматгиз, 1966

[7] Интегральные операторы в пространствах суммируемых функций. М.: Наука, 1966 (совм. с П.П. Забрейко и др.)

[8] Интегральные уравнения. М.: Наука, 1966 (совм. с П.П. Забрейко и др.)

[9] Приближенные решения операторных уравнений. М.: Наука, 1969 (совм. с Г. М. Вайникко др.)

[10] Нелинейные почти периодические колебания. М.: Наука, 1970 (совм. с В.Ш. Бурдом и Ю.С. Колесовым)

[11] Геометрические методы нелинейного анализа. М.: Наука, 1975 (совм. с П.П. Забрейко)

[12] Системы с гистерезисом. М.: Наука, 1983 (совм. с А. В. Покровским)

[13] Позитивные линейные системы. М.: Наука, 1985 (совм. с Е.А. Лившицем и А. В. Соболевым)

[14] Анализ устойчивости рассинхронизированных систем. М.: Наука, 1992 (совм. с Е. А. Асариным, В.С. Козякиным и Н.А. Кузнецовьм) 